\title{
THE USE OF MODIFIED CLAY MATERIALS FOR THE SORPTION OF VARIOUS INDUSTRIAL POLLUTANTS
}

\author{
Hartmut POLZIN ${ }^{1}$, Jiří PAVLOVSKÝ ${ }^{2}$, Lenka HERECOVÁ ${ }^{3}$, Dalibor MÍČEK ${ }^{4}$, \\ Martin MUCHA ${ }^{5}$, Helena DOLEŽALOVÁ WEISSMANNOVÁ ${ }^{6}$, Soňa ŠTUDENTOVÁ ${ }^{7}$, \\ Iveta VASKOVÁ ${ }^{8}$
}

Research article

\begin{tabular}{ll}
\hline Abstract: & The Authors dealt with the use of modified clay materials for the removal of dangerous \\
& industrial pollutants. Three modification methods (namely modification by Keggin's \\
& polycation, modification by means of humic substances and pillarization at $450^{\circ} \mathrm{C}$ ) were \\
& applied for the creation of modified materials. Clay materials modified by humic substances \\
& were used for the sorption of $\mathrm{Cr}(\mathrm{VI})$ from aqueous medium in the form of dichromates. Other \\
& ways of modification and their combinations were used for the preparation of the sorbents of \\
& dangerous gaseous pollutants (toluene, xylene). It was discovered that some modified clay \\
& materials sorb the gaseous pollutants twice as much as common sorbent (activated carbon). \\
Keywords: & Sorption, montmorillonite, humic substances, pillarization.
\end{tabular}

\section{Introduction}

Dangerous pollutants escaping as by-products of industrial activities pollute the atmosphere, soil, and water. Contaminated sands, prone to releasing harmful emissions, are the key to potential environmental impacts in foundry industry. Many possibilities of retaining these pollutants exist, however they are not sufficient for the removal of all the industrial pollutants out of the natural environment (Gonen and Rytwo, 2006). Therefore it is necessary to find new ways of dangerous pollutants disposal, both organic and inorganic. Organic volatile substances rank among watched organic industrial pollutants (Shih and Chou, 2010; Jarraya et al., 2010). So called BTEX substances (benzene, toluene, ethylbenzene, xylene) belong into this group. Benzene is surely the most dangerous BTEX substance, since it is neurotoxic at acute action and has narcotic effect. At chronic action, it has hematotoxic effects, influencing blood formation. It is considered carcinogen and teratogen. Toluene has inhalation and transdermal effects. Xylene is strongly narcotic, it causes headache, nausea, lassitude, and weariness; unconsciousness at higher concentrations (Tichý, 2004). In foundry industry, these substances originate during the casting of metal into the mixtures bound by organic resins and due to their volatility they can contaminate both water and air. BTEX emissions are expected especially at the casting and cooling of casts, as well as at disconnection of cast-iron castings from the mould material.

Heavy metals are often watched inorganic substances. Chrome is an interesting element from the toxicity and danger point of view, especially $\mathrm{Cr}(\mathrm{VI})$, known by it carcinogenicity. It originates during industrial ore treatment by the process of leaching or is present in sludge pits and sump tanks or in soils impacted by industrial activities. $\mathrm{Cr}$ (VI) causes skin pustules, blood forming disorders, even nasal septum, tympanum and jaw perforations, leukemia and death at higher concentrations (Tichý, 2004). Cr(VI) does not occur much as a pollutant at foundry industry but its presence cannot be ruled out. It can cause the contamination of base raw materials or certain processes, possibly the contamination of the concrete mould mixture.

Sorption on suitable materials is one possibility for eliminating these dangerous substances from the environment. Clay materials are often used for

TU Bergakademie Freiberg, Gießerei-Institut, Freiberg, Deutschland, polzin@gi.tu-freiberg.de

2 VŠB - Technical University of Ostrava, Faculty of metallurgy and material engineering, Ostrava, Czech Republic, jiri.pavlovsky@vsb.cz

3 VŠB - Technical University of Ostrava, Faculty of safety Engineering, Ostrava, Czech Republic, lenka.herecova@vsb.cz

4 VŠB - Technical University of Ostrava, Faculty of safety Engineering, Ostrava, Czech Republic, dalibor.micek@vsb.cz

5 VŠB - Technical University of Ostrava, Faculty of metallurgy and material engineering, Ostrava, Czech Republic, martin.mucha@vsb.cz

6 VUT Brno, Faculty of chemistry, Purkyňova 464/118, 61200 Brno, Czech Republic, dolezalova@fch.vutbr.cz

7 VŠB - Technical University of Ostrava, Faculty of metallurgy and material engineering, Ostrava, Czech Republic, sona.studentova@vsb.cz

$8 \quad$ TU Košice, Faculty of metallurgy, Košice, Slovak Republic, iveta.vaskova@tuke.sk 
this purpose, since they can be properly modified to increase their sorption ability. Modified clay materials can be used for the sorption both from aqueous media, when especially heavy metals $(\mathrm{Cu}, \mathrm{Ag}, \mathrm{Cd}$, $\mathrm{Pb}, \mathrm{Zn}, \mathrm{Hg}$ etc.) are sorbed (Plee et al. 1985; Weiss et al., 1998), and from gaseous media, to remove the dangerous volatile organic substances (benzene, toluene, xylene, naphthalene) (Houari et al, 2007; Ruiz et al., 1998). This approach represents very good opportunity for practical applications, since $70 \%$ of molds used today are bonded by uniform bentonite mixture. Modified bentonite mixtures could serve directly for the removal of industrial pollutants.

Two workplaces of the VŠB - Technical University of Ostrava study the problems of clay materials modification in the long term, namely the Centrum of nanotechnologies and the Department of analytical chemistry and testing of materials. The requirements for removing the pollutants from foundry process in foundries were defined in the cooperation with the Institute of foundry industry at TU Bergakademie Freiberg. The authors (Plachá, et al., 2008; Plachá, et al., 2011) studied the sorption of naphthalene on vermiculite that was modified by hexadecyltrimethylamonia bromide or by the monohydrate of hexadecylpyridinium chloride - this study was performed in the framework of the research plan MSM 6198910016 "Synthesis, structure and properties of nanomaterials based on intercalated phylosilicates" (2005 - 2011, MSM). The project GP 104/08/P274 - "The Study of properties and use of clay materials after intercalation by inorganic and organic cations (2008 - 2010, GA0/GP) was another research project in this field. Its solver deals, among other things, with the intercalation of clay materials by Keggin's cation and with the sorption of organic molecules (toluene and xylene) on intercalated clay materials or the sorption of humic substances on clays (Pavlovský et al., 2009; Pavlovský et al., 2010). The authors of this article relate closely to this project, studying the sorption of dangerous pollutants from both the aquatic - Cr(VI) and gaseous media - toluene, xylene.

\section{Materials and methods}

The standard of the type SWy-2 (Na-rich Montmorillonite-MMT, Crook County, Wyoming, USA) was chosen as a feedstock for the assessment of the sorption abilities of modified clay materials. This sodium form of montmorillonite treated by sedimentation in order to remove silicon out of the sample, with the following parameters: basal diffraction $d_{001} 1,21 \mathrm{~nm}$, specific surface $S \quad 26,8 \mathrm{~m}^{2} \cdot \mathrm{g}^{-1}$, CEC (ion exchange capacity) 1,21 meq. $\mathrm{g}^{-1}$, particle size $<5 \mu \mathrm{m}$.
The clay material was intercalated by the commercial solution Chlorhydrol (Reheis company, USA, $50 \%$ solution with the chemical composition $\mathrm{Al}_{2} \mathrm{Cl}(\mathrm{OH})_{5}$. $\left(2,5 \quad \mathrm{H}_{2} \mathrm{O}\right)$, molar ratio $\left.\mathrm{OH} / \mathrm{Al} 2,5\right)$ and by humic substance (HS) Humagra ${ }^{\circledR}$ Liquid 10-4-6 (Humintech, GmbH Düsseldorf, Germany, potassium form HS (humic acids content - HA $18 \%$, nitrogen (urea) $10 \%$, phosphoric oxide $4 \%$, potassium oxide dissolved $6 \%$, iron $0,2 \%$, pH 8 - 9, density 1,23 kg.dm ${ }^{-3}$, CEC $300-500 \mathrm{meq} / 100 \mathrm{~g}$ ).

Activated carbon CS type (specific surface $S$ $1261,7 \mathrm{~m} 2 . \mathrm{g}^{-1}$, made from coconut shells, iodine number $1050 \mathrm{~kg} . \mathrm{m}^{-3}$, Endler Ltd., Děčín X-Bělá, Czech Republic) was chosen for the comparison of the sorption of gaseous pollutants with common sorbent.

The following industrial pollutants were ranked among the watched sorbed substances:

- toluene, xylene (p.a., Merci Ltd., Czech Republic) for the gaseous phase sorption on pillarized and inorganically intercalated clay materials,

- $\mathrm{Cr}(\mathrm{VI})$ for the sorption in the form of dichromates $\left(\mathrm{K}_{2} \mathrm{Cr}_{2} \mathrm{O}_{7}\right.$, p.a., Merci Ltd., CR) from the aqueous media on organically intercalated clay materials (Pavlovský et al., 2011).

\section{Modification of clay materials}

Montmorillonite based clay materials are used abundantly for sorption thanks to their properties such as high specific surface and porosity. These materials are modified for the improvement of their sorption abilities. The following methods are most often used for modification:

- pillarization,

- inorganic intercalation,

- organic intercalation.

These modifications can be mutually combined, too (Lahav, et al., 1978; Michot et al., 1993; Kloprogge et al., 1999). Pillarization is a process when the clay material is heated to the temperature of approx. $450{ }^{\circ} \mathrm{C}$. The structure change occurs at this temperature (Fig. 1), which results into the increase of interlaminar distance and of specific surface and the improvement of other texture parameters (pore size and distribution etc.). During inorganic intercalation, big inorganic molecules (e.g. Keggin's cation) penetrate into montmorillonite interlayer (Fig. 2) (Lambert et al., 1994). Intercalate prepared in this way again demonstrate increased interlaminar distance and specific surface (Moore et al., 1997). Nevertheless, the selectivity of sorbed substances or their subsequent degradation can be influenced by the selection of suitable molecule. Organic intercalation 
can proceed, for example, with the help of so called humic substances (HS), which tie on clay material by chelation, van der Waals' forces, bridges etc. Tied HS can then have positive effect on the sorption of dangerous industrial pollutants (Feng et al., 2005).

The authors used all the above mentioned modifications, including the combination of inorganic modification and pillarization, for the assessment of the sorption abilities of modified clay materials.

The inorganic intercalation of SWy-2 was realized by two processes. During the first preparation method, the $\mathrm{pH}$ value was adjusted only at the beginning of saturation process (procedure I). The second method of intercalate preparation (procedure II.) was based on the adjusting of $\mathrm{pH}$ value during the whole saturation process (constant $\mathrm{pH}$ value was secured during the whole process). Both procedures were performed at ordinary laboratory conditions and at three $\mathrm{pH}$ values. Prepared intercalates were subsequently dried at the temperature of $40^{\circ} \mathrm{C}$ or pillarized at the temperature of $450{ }^{\circ} \mathrm{C}$. The process is described in detail in the publications (Pavlovský et al., 2009: Pavlovský et al., 2010).

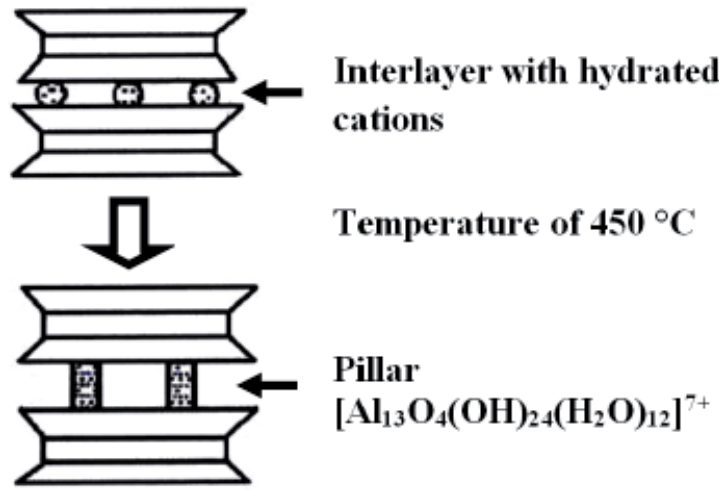

Fig. 1 Schematic representation of pillarization process (Moore et al., 1997)

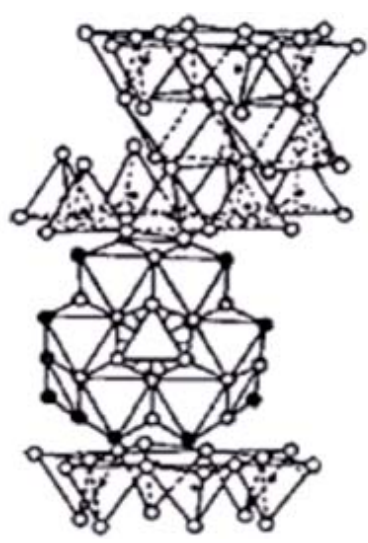

Tetrahedric layer

Octaahedric layer

Tetrahedric layer

$\mathrm{Al}_{13}{ }^{7}$ polycation Keggin's

Fig. 2 Schematic representation of intercalation process (Lambert et al., 1994)

The structure of original clay material SWy-2 (SEM, enlarged 1000 times) is shown in Fig. 4. The structure of intercalated clay material Al-SWy-2 (procedure I, pH 3.8, SEM, enlarged 500 times) is shown in Fig. 3. The intercalation process can be clearly seen in Fig. 1, which presents itself by the enlargement of interlayer space (higher value of $d_{001}$ ). The material is not compact; instead it has porous structure with relatively developed texture. On the other hand, the SEM picture of original clay in Fig. 4 shows that silicate layers are not so distant (lower value of $d_{001}$ ).

Organic intercalation was realized by HS. It was discovered (Li et al., 2010) that the presence of aluminum cations has positive effect on sorption. That is why Al(III) cations in the concentration of 3 mmol.g ${ }^{-1}$ of clay were added into the structure of original clay SWy-2 before intercalation. Thereby, the ability of clay materials to tie $\mathrm{Cr}(\mathrm{VI})$ ions improved (Koběrská, 2010). Clay materials treated in this way were subsequently intercalated by the practice described in (Pavlovský et al., 2011), saturation process B. Organic intercalation was performed at $\mathrm{pH}$ value 1 .

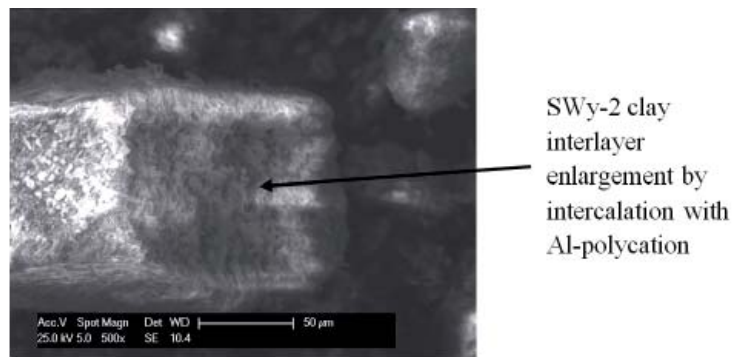

Fig. 3 SEM picture of Al-SWy-2 intercalate after the intercalation of original SWy-2 clay with Al-polycation, enlarged 500 times, $\mathrm{pH} 3.8$, intercalation procedure I

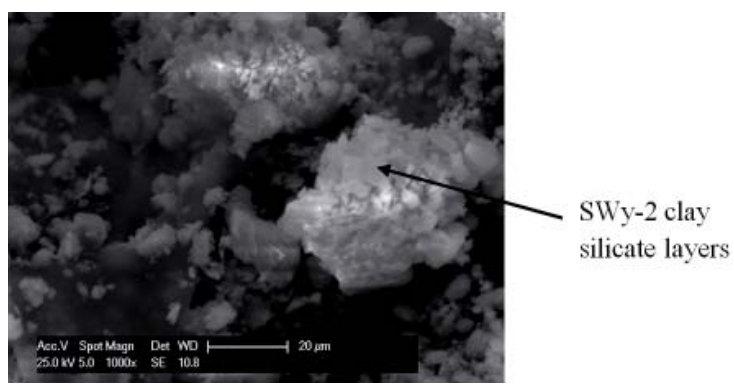

Fig. 4 SEM picture of original SWy-2 clay, enlarged 1000 times

\section{Sorption of dangerous pollutants}

The sorption of organic vapors was performed gravimetrically in desiccator at the maximum equilibrium vapor concentration of given pollutant. The shots of intercalates were in the amount of approx. $30 \mathrm{mg}$ to $40 \mathrm{mg}$, those of common sorbents 
in the amount of approx. $100 \mathrm{mg}$ to $120 \mathrm{mg}$. All materials were regularly weighed during the sorption process at 60-minute intervals. Most sorbents including intercalates achieved the maximum state of gaseous pollutants sorption within 4 hours from the beginning of the saturation process.

The saturation process of $\mathrm{Cr}(\mathrm{VI})$ in the form of dichromates anions was done for two $\mathrm{pH}$ values (non-adjusted $\mathrm{pH}$ value and $\mathrm{pH}=1$ ). Clay material SWy-2 modified by Al(III) ions was used as sorbent.

Total amount of sorbed $\mathrm{Cr}(\mathrm{VI})$ was determined by VIS spectroscopy method according to the standard ČSN ISO 11083 (75 7424) Determination of chrome (VI) - Spectrophotometric method with 1,5-diphenylcarbazide. $\mathrm{Cr}(\mathrm{VI})$ reacts with 1,5 diphenylcarbazide and red-violet complex chrome-1,5-diphenylcarbazide occurs. Absorbance of this complex was then measured at the wave length $542 \mathrm{~nm}$ against demineralized water in $1 \mathrm{~cm}$ silica glass cuvettes. Saturating solutions were diluted 100 250 times due to their higher concentrations, because the calibration series according to this standard was prepared up to maximum concentration of $10 \mu \mathrm{mol}$ $\mathrm{Cr}(\mathrm{VI}) / \mathrm{l}(0,52 \mathrm{mg} \mathrm{Cr}(\mathrm{VI}) / \mathrm{l}),(\mathrm{A}=0,0366 . \mathrm{c}+0,0615$; correlation coefficient $\left.r^{2} 0,9984\right)$.

Langmuir's adsorption isotherm (Langmuir, 1918; Hall et al. 1966) was used for the assessment of $\mathrm{Cr}(\mathrm{VI})$ ions sorption on clay materials, that was theoretically derived on the assumption of balanced adsorption on the whole surface, see equation (1):

$$
a=a_{m} \cdot \frac{b \cdot c_{e}}{1+b \cdot c_{e}}
$$

where:

$a$ is an adsorbed amount [mmol. $\left.\mathrm{g}^{-1}\right]$,

$a_{m}$ is a maximum adsorbed amount [mmol. $\mathrm{g}^{-1}$,

$c_{e}$ is a balanced concentration [mmol.g $\left.{ }^{-1}\right]$,

$b$ is an equilibrious constant characterizing the relation between adsorbent and adsorbate [-].

This isotherm type is commonly used in practice for the sorption of metals on clay materials, because this method proves to be the most accurate according to reliability criteria derived by non-linear regression. Multiple correlation coefficient (R) and Akaike's information criterion (AIC - the smaller its value, the more accurate isotherm) rank among the main reliability criteria. The value of the mean square error of prediction (MEP) is important as well - the closer to zero, the more accurate isotherm (Li et al., 2010).

\section{Results}

Six types of inorganic intercalates were prepared by the above mentioned method and were used for the sorption of gaseous industrial pollutants vapors (xylene, toluene). Sorbed gas amounts on individual intercalates represented by the mass growth after saturation are resumed in Table 1.

Tab. 1 The sorption of organic pollutants vapors represented by the mass growth after saturation (Pavlovský et al., 2009; Pavlovský et al., 2010)

\begin{tabular}{ccccc}
\hline $\begin{array}{c}\text { Sorbing gases } \\
\text { Temperature at } \\
\text { materials preparation } \\
\text { [ }{ }^{\mathbf{C}} \text { ] }\end{array}$ & $\mathbf{4 0}$ & $\mathbf{4 5 0}$ & $\mathbf{4 0}$ & $\mathbf{4 5 0}$ \\
$\begin{array}{c}\text { Samples marking } \\
\text { SWy-2 }\end{array}$ & \multicolumn{4}{c}{ Mass growth [mass \%] } \\
\hline Al-SWy-2, I., pH 1,5 & 5,15 & 12,16 & 7,32 & 6,13 \\
Al-SWy-2, II., pH 1,5 & 23,02 & 21,26 & 15,13 & 23,53 \\
Al-SWy-2, I., pH 2,0 & 4,35 & 11,41 & 2,10 & 4,40 \\
Al-SWy-2, II., pH 2,5 & 3,65 & 11,41 & 2,04 & 6,48 \\
Al-SWy-2, I., pH 3,8 & 9,82 & 37,86 & 5,77 & 21,37 \\
Al-SWy-2, II., pH 3,8 & 8,57 & 31,86 & 4,20 & 18,12 \\
activated carbon CS & 15,16 & - & 13,29 & - \\
\hline
\end{tabular}

For the assessment of the effect of HS intercalation on the sorption of $\mathrm{Cr}(\mathrm{VI})$ in the form of dichromate anions, the sorption was done not only on intercalate HS-clay-(Al) but also on clay material treated only by aluminum cations, that means by clay-(Al) material.

Maximum adsorbed amounts of $\mathrm{Cr}(\mathrm{VI})$ on individual modified materials that were determined from the Langmuir's isotherm, including the parameters of non-linear regression in QC-Expert Trilobyte, version 6.1. software, are resumed in Tab. 2.

\section{Discussion}

Measured data show that the modification of clay materials have strong influence on their sorption abilities. It follows from Table 1 that not only the $\mathrm{pH}$ value and the preparation mode of intercalated material but also subsequent pillarization at the temperature of $450{ }^{\circ} \mathrm{C}$ have considerable effect on the sorption abilities of given material. The mode of the preparation of intercalates marked procedure II (constant $\mathrm{pH}$ value during the whole process of the saturation by Al-polycation) has positive influence on the sorption abilities of prepared materials, when, in some cases, the sorption ability can increase by more than $100 \%$ (Al-SWy-2, II, pH 1.5). Subsequent pillarization increases sorption ability of intercalates as well, in case of Al-SWy-2, prepared by procedure I at $\mathrm{pH}$ value 3.8 , by $350 \%$. Maximum sorption of individual gaseous pollutants are determined at 
Tab. 2 Parameters of adsorption isotherm at $\mathrm{Cr}(\mathrm{VI})$ sorption on $\mathrm{SWy}-2$ and intercalates

\begin{tabular}{|c|c|c|c|c|c|c|}
\hline Material & $\begin{array}{l}\text { pH value during } \\
\text { sorption } \mathrm{Cr}(\mathrm{VI})\end{array}$ & $\begin{array}{c}\text { Presence of } \mathrm{Al}(\mathrm{III}) \\
\text { in intercalate } \\
\mathrm{Cr}(\mathrm{VI})\end{array}$ & $\begin{array}{c}\text { Maximum } \\
\text { adsorbed amount } \\
\mathrm{a}_{\mathrm{m}}(\mathrm{mg} \mathrm{Cr}(\mathrm{VI}) / \mathrm{g} \text { of } \\
\text { clay) }\end{array}$ & $\mathbf{R}$ & AIK & MEP \\
\hline \multirow{4}{*}{ SWy-2 } & $\mathrm{pH} 1$ & yes & $22,95 \pm 1,06$ & 0,9926 & $-65,6$ & 0,00067 \\
\hline & & no & 0 & - & - & - \\
\hline & without $\mathrm{pH}$ & yes & $29,12 \pm 1,56$ & 0,9934 & $-72,0$ & 0,00081 \\
\hline & adjustment & no & 0 & - & - & - \\
\hline \multirow{4}{*}{$\begin{array}{l}\text { HL-SWy-2, } \\
\text { process B } \\
\text { (preparation at } \\
\text { pH 1) }\end{array}$} & pH 1 & yes & $22,11 \pm 1,15$ & 0,9936 & $-60,5$ & 0,00051 \\
\hline & & no & $28,60 \pm 2,60$ & 0,9833 & $-64,9$ & 0,00155 \\
\hline & without $\mathrm{pH}$ & yes & $34,32 \pm 1,04$ & 0,9973 & $-87,9$ & 0,00034 \\
\hline & adjustment & no & 0 & - & - & - \\
\hline
\end{tabular}

$\mathrm{R}$ - multiple correlation coefficient, AIK - Akaike's information criterion, MEP - mean square error of prediction.

various intercalate types. In case of xylene, it is the pillarized intercalate Al-SWy-2, II, pH 1.5, whereas maximum amount of toluene was adsorbed by pillarized intercalate Al-SWy-2, II, $\mathrm{pH}$ 3.8. In this comparison the intercalate Al-SWy-2, II, pH 1.5 proved to be the best adsorbent, having sorbed both substances more than activated carbon, in pillarized state as well as before pillarization.

As far as the sorption of $\mathrm{Cr}(\mathrm{VI})$ in the form of dichromates, the intercalation by humic substances helps to remove $\mathrm{Cr}(\mathrm{VI})$ cations of aqueous solutions. The preparation of intercalates plays an important role, as well as the conditions during $\mathrm{Cr}(\mathrm{VI})$ sorption ( $\mathrm{pH}$ value). Positive influence of the presence of aluminum ions in the structure of intercalates, helping the sorption of $\mathrm{Cr}(\mathrm{VI})$, was proved. Table 2 shows that original SWy-2 clay did not adsorb $\mathrm{Cr}(\mathrm{VI})$ at all. On the other hand, the intercalate with humic substance and aluminum ions (34.32 \pm $1.04 \mathrm{mg} \mathrm{Cr.g^{-1 }}$ of clay) showed the best sorption properties.

\section{Conclusion}

Measured data prove that the modification of clay materials has positive effect on their sorption abilities. Three modes of modification were applied: by inorganic polycation, by humic substances and by pillarization process at $450{ }^{\circ} \mathrm{C}$. Prepared intercalates were used for the sorption of dangerous industrial pollutants (toluene, xylene, $\mathrm{Cr}(\mathrm{VI})$ ). The effect of conditions at the preparation of modified clay materials was assessed as well. In case of inorganic modification, $\mathrm{pH}$ value has a strong effect. As far as the organic modification by humic substances is concerned, the assumption that the presence of aluminum cations in the structure of clay material improves the sorption of $\mathrm{Cr}(\mathrm{VI})$ improves sorption was verified. The pillarization temperature of $450{ }^{\circ} \mathrm{C}$ has positive effect as well. The results provide processes leading to the improvement of environment in a foundry by the adsorption of polluting substances originating from mould mixtures. To prevent the occurrence of harmful substances is the best way of the improvement of the environmental sustainability of production. However, this is not possible due to the high use of core mixtures with organic binders. That is why the methods of the adsorption of polluting substances by modified bentonites are a valuable contribution to the improvement of situation.

\section{Acknowledgements}

The authors appreciate the Grant agency of the Czech Republic for the institutional support of the project 104/08/P274 and the Regional materialtechnology research center(RMTVC) for the financial support of the project CZ.1.05/2.1.00/01.0040.

\section{References}

ČSN ISO 11083 (75 7424):1996. Jakost vod - Stanovení chromu (VI) - Spektrofotometrická metoda s 1,5-difenylkarbazidem.

FENG X., SIMPSON A.J., SIMPSON M.J. (2005) Chemical and mineralogical controls on humic acid sorption to clay mineral surfaces. Organic Geochemistry, 2005, Vol. 36, No. 11, pp. 1553-1566. ISSN 0146-6380.

GONEN, Yotam, RYTWO, Giora (2006). Using the dual-mode model to describe adsorption of organic pollutants onto an organoclay. Journal of Colloid and Interface Science, 2006, Vol. 299, No. 1, pp. 95-101. ISSN 0021-9797.

HALL, K.R., EAGLETON, L.C., ACRIVOS, A., VERMEULEN, T. (1966). Pore- and solid-diffusion kinetics in fixed-bed adsorption under constant-pattern conditions. Industrial \& Engineering Chemistry Fundamentals, 1966, Vol. 5, No. 2, pp. 212-\&. ISSN 0196-4313. 
HOUARI, M., HAMDI, B., BRENDLE, J., BOURAS, O., BOLlinGER, J.C., BAUDU, M. (2007). Dynamic sorption of ionizable organic compounds (IOCs) and xylene from water using geomaterial-modified montmorillonite. Journal of Hazardous Materials, 2007, Vol. 147, No. 3, pp. 738-745. ISSN 0304-3894.

JARRAYA, Ikram, FOURMENTIN, Sophie, BENZINA, Mourad, BOUAZIZ, Samir (2010). VOC adsorption on raw and modified clay materials. Chemical Geology, 2010, Vol. 275, No. 1-2, pp. 1-8. ISSN 0009-2541.

KLOPROGGE, J.T., FRY, R., FROST, R.L. (1999). An infrared emission spectroscopic study of the thermal transformation mechanisms in Al-13-pillared clay catalysts with and without tetrahedral substitutions. Journal of Catalysis, 1999, Vol. 184, No. 1, pp. 157-171. ISSN 0021-9517.

KOBĚRSKÁ, Z. (2010). Interkalace jílových minerálů huminovými kyselinami, Diplomová práce, 2010, Ostrava, p. 55.

LAHAV, N., SHANI, U., SHABTAI, J. (1978). Cross-Linked Smectites .1. Synthesis and Properties of HydroxyAluminum-Montmorillonite. Clays and Clay Minerals, 1978, Vol. 26, No. 2, pp. 107-115. ISSN 0009-8604.

LAMBERT, J.F., CHEVALIER, S., FRANCK, R., SUQUET, H., BARTHOMEUF, D (1994). Al-pillared Saponites. 2., NMR studies. Journal of the Chemical Society-Faradyz Transactions, 1994, Vol. 90, No. 4, pp. 675-682. ISSN 0956-5000.

LANGMUIR, I. (1918). The adsorption of gases on plane surfaces of glass, mica and platinum. Journal of the American Chemical Societ, 1918, Vol. 40, pp. 1361-1403. ISSN 0002-7863.

LI, Ying, YUE, Qin-Yan, GAO, Bao-Yu (2010). Effect of Humic Acid on the Cr(VI) Adsorption onto Kaolin. Applied Clay Science, 2010, Vol. 48, No. 3, pp. 481-484. ISSN 0169-1317.

MICHOT, L.J., BARRÈS, O., HEFT, E.L., PINNAVAIA, T.J. (1993). Cointercalation of Al13 Polycations and Nonionic Surfactants in Montmorillonite Clay. Langmuir, 1993, Vol. 9, No. 7, pp. 1794-1800. ISSN 0743-7463.

MOORE, D.M., REYNOLDS, R.C. (1997). X-Ray diffraction and the identification and analysis of clay minerals, Oxford, $2^{\text {nd }}$. edit., New York, 1997, p. 109.

PAVlOVSKÝ, J., HERECOVÁ, L., MÍČEK, D., VĚŽNÍKOVÁ, H., MUCHA, M., ŠTUDENTOVÁ, S., DOLEŽALOVÁ WEISSMANNOVÁ, H. (2009). Využití nových materiálů na bázi jílových minerálů pro sorpci nebezpečných plynných polutantů. SPEKTRUM, Ostrava, 2009, Vol. 9, No. 1, pp. 68-71. ISSN 1211-6920.

PAVlOVSKÝ, J., HERECOVÁ, L., MÍČEK, D., VĚŽNÍKOVÁ, H., MUCHA, M., ŠTUDENTOVÁ, S., DOLEŽALOVÁ WEISSMANNOVÁ, H. (2010). Modifikované jílové minerály jako sorbenty organických plynných polutantů. SPEKTRUM, Ostrava, 2010, Vol. 10., No. 1, pp. 50-54. ISSN 1211-6920.

PAVlOVSKÝ, J., HERECOVÁ, L., MÍČEK, D., VĚŽNÍKOVÁ, H., MUCHA, M., ŠTUDENTOVÁ, S., DOLEŽALOVÁ WEISSMANNOVÁ, H., KOBĚRSKÁ, Z., VASKOVÁ, I. (2011). Sorbenty na bázi jíl-huminová látka a jejich využití pro sorpci dichromanů. SPEKTRUM, 2011, Vol. 11., No. 1, pp. 54-59. ISSN 1211-6920.

PLACHÁ, Daniela, MARTYNKOVÁ SIMHA, Gražyna, RÜMMELI, Mark H. (2008) Preparation of organovermiculites using HDTMA: Structure and sorptive properties using naphthalene, Journal of Colloid and Interface Science, 2008, Vol. 327, No. 2, pp. 341-347. ISSN 0021-9797.

PLACHÁ, Daniela, MARTYNKOVÁ SIMHA, Gražyna, KUKUTSCHOVÁ, Jana (2011). Sorption of Naphthalene Vapor on Organomodified Vermiculite. Chemické listy, Praha, 2011, Vol. 105, No. 3, pp. 186-192. ISSN 0009-2770.

PLEE, D., BORG., F., GATINEAU, L., FRIPIAT, J. J. (1985). High-resolution solid-state aluminum-27 and silicon-29 nuclear magnetic resonance study of pillared clays. Journal of the American Chemical Society, 1985, Vol. 107, No. 8, pp. 2362-2369.

RUIZ, J., BILBAO, R., MURILLO, M.B. (1998). Adsorption of different VOC onto soil minerals from gas phase: Influence of mineral, type of VOC, and air humidity. Environmental Science \& Technology, 1998, Vol. 32, No. 8, pp. 1079-1084. ISSN 0013-936X.

SHIH, Yang-Hsin, CHOU, Shih-Min (2010). Characterization of Adsorption Mechanisms of Volatile Organic Compounds with Montmorillonite at Different Levels of Relative Humidity via a Linear Solvation Energy Relationship Approach. Journal of Chemical and Engineering Data, 2010, Vol. 55, No. 12, pp. 5766-5770. ISSN 0021-9568.

TICHÝ, Miloň (2004). Toxikologie pro chemiky - Toxikologie obecná, speciální, analytická a legislativa. $2^{\text {nd }}$. edit. Karolinum, Czech Republic: Prague, 2004. 119 p. ISBN 80-246-0566-X.

WEISS, Z., KLIKA, Z., ČAPKOVÁ, P., JANEBA, D. (1998). Sodium-cadmium and sodium-zinc exchangeability in montmorillonite. Physics and Chemistry of Minerals, 1998, Vol. 25, No. 7, pp. 534-540. ISSN 0342-1791. 